Marquette University

e-Publications@Marquette

$1-1-2005$

\title{
Zabarella, Prime Matter, and the Theory of Regressus
}

James B. South

Marquette University, james.south@marquette.edu

Published version. Graduate Faculty Philosophy Journal, Vol. 26, No. 2 (2005): 79-98. DOI. (C) 2005 Graduate Faculty Philosophy Journal. Used with permission. 


\title{
Zabarella, Prime Matter, and the Theory of Regressus
}

\author{
James B. South
}

\section{Introduction: Matter and Zabarella's Methodology}

The sixteenth-century philosopher Jacopo Zabarella (1533-1589) stands near the end of the long Aristotelian dominance of western academic philosophy. Yet, despite the fact that Aristotelianism was soon to be overwhelmed by other currents of thought, Zabarella's influence on western thought would continue into at least the nineteenth century, and he still provides useful discussions relevant to today's Aristotle scholars. ${ }^{1}$ In what follows, I discuss the existence and essence of matter, and show how Zabarella argues for his claims. What is especially notable about the existence and essence of matter as a topic is that matter is clearly at the center of his well-known interest concerning the nature of scientific methodology.

In his work De regressu, Zabarella sets forth, in a programmatic way, his account of scientific reasoning. In this methodological treatise, he gives pride of place to the example of matter as fitting precisely the requirements of the theory. At the same time, though, his discussion of matter in the De regressu is highly compressed, which is not surprising since it is only proposed as an example. Rather more surprising is that scholars writing on the De regressu do not pay attention to Zabarella's fully developed account of matter in his work De prima rerum materia. That is an unfortunate oversight since the discussion of matter in the De prima rerum materia provides us with a chance to see Zabarella working on a problem that he thinks is eminently suitable for his account of scientific methodology. By using these two works to illuminate each other, I hope to provide an insight into the unity of Zabarella's methodological concerns and his philosophy of nature.

In what follows, then, I am interested in exploring what Zabarella thinks about matter only insofar as it relates to his methodological concerns. Of course, he is part of a long tradition of discussion about the 
nature of matter as a kind of being (ens) - the De prima rerum materia contains a long discussion of that topic. Yet an exhaustive discussion of Zabarella's attempt to bring this nature to light would distract us from observing the way in which his method of regressus is present in the treatise on prime matter. In fact, Zabarella himself makes a distinction that justifies my treatment of the issue when he points to two different ways of thinking about matter. There are, he writes, two considerations (considerationes), or notions (notiones), of matter. In brief, we can think about matter absolutely as it is in itself, or we can think about it relatively, that is, as a principle of other things:

Some things are attributed to a man insofar as he is a man, and other things are attributed to him insofar as he is a father. So too, some things are attributed to matter according to its first notion and as a being [ens], but other things are attributed to it in terms of its second notion insofar as it is a principle and referred to other things. ${ }^{2}$

While I shall explain the importance of this distinction and its philosophical significance in the third part of the essay, for now it is sufficient to note it as providing an explanation for the focus of what follows.

As a final prelude to the discussion of matter and methodology, it is worth pausing to notice Zabarella's general procedure in the De prima rerum materia. After disentangling some issues in a debate between Scotists and Thomists concerning the idea of prime matter in God's mind, Zabarella essentially dismisses the topic: "But let us abandon theological disputation about this issue. . . . My purpose [consilium] is not to dispute in a theological manner [Theologice], but in an Aristotelian one [Aristotelice]."

In fact, Zabarella never wanders too far from an Aristotelian orbit concerning any philosophical problem, and he makes clear his goal for the treatise on prime matter when he says that by the end of the work "I shall have endeavored (if I can) to make clear the truth and the opinion of Aristotle about prime matter." The obvious reading of this goal is that the truth and Zabarella's account of Aristotle's opinion are one and the same. We receive striking confirmation of Zabarella's unswerving commitment to Aristotelian language when he writes:

We say properly and absolutely that substances are generated and corrupted, but we say less properly and, as they say, relatively [secundum quid], that accidents are generated and corrupted. For if water is generated from air, we say simply [simpliciter] that water comes to be. But if water comes to be warm from cold water, we do not say simply that the water comes to be, but that the water becomes warm. Hence, we conclude [colligimus] that the same 
change [mutatio] in accidents can be called both generation and motion [motus] because of various considerations. For we can call that warming of the water 'generation' insofar as something warm comes to be from what is not warm, having been formed [formatum] by something having been taken away [privatum]. But insofar as there is a passage [transitus] from cold to warm, from form to form, and, as they say from something positive to something positive, to that extent it is called motion [motus]. ${ }^{5}$

In addition to introducing us to some terms central to his ensuing discussion, this passage, with its iterations of "we say" and "as they say," also has about it the unmistakable air of an invitation to, or even an initiation into, a way of thinking about the issue of change. Placed just prior to Zabarella's discussion of the existence of prime matter, it also shows that he recognizes that there is a strong connection between the phenomena associated with change and the introduction of prime matter. That connection will prove crucial to my explication of Zabarella's account of prime matter.

\section{Induction and the Existence of Prime Matter}

In his De regressu, Zabarella sets forth a scientific methodology known as regressus. The outline of the theory looks simple enough. There are three steps involved. Having noticed some effect existing in nature, we ask about the cause of that effect. We then proceed to demonstrate the existence of that cause through a demonstration showing that the cause exists. Zabarella calls this first demonstrative argument either a "demonstration quia" or a "demonstration from an effect." But this demonstration only gives us knowledge that a cause exists, while we are left unsure of the nature of the cause. Consequently, we consider the nature of the cause, coming to some understanding of its nature. Once we have clarified the nature of the cause, we can use that known cause to argue back to the effect in a demonstration that shows why the effect follows from the cause. This latter demonstration Zabarella calls a "demonstration propter quid." Zabarella summarizes regressus in the following way: "It is a certain sort of reciprocated demonstration such that after we have demonstrated the unknown cause from the known effect, we convert the major premise and then demonstrate the same effect through the same cause, so that we might know why it is." Of course, this is only meant as an overview. By actually looking at the example of prime matter, we will gain a better sense of Zabarella's project.

In the third chapter of the De prima rerum materia, Zabarella attempts to prove the existence of prime matter. He entitles the chap- 
ter "Concerning the Discovery of Prime Matter" (De Inventione Primae Materiae), though "discovery" may be a misleading way of thinking about what Zabarella is really doing, if by discovery we mean something along the lines of a modern view of experimentation. ${ }^{8}$ As with many of his technical terms, it is best to let any definition emerge from its use. So, when Zabarella claims to discover the existence of prime matter, he does so with the following argument:

(1) Where there is substantial change, there is a subject matter.

(2) In all natural bodies, there is substantial change.

Therefore,

(3) In all natural bodies, there is a subject matter. ${ }^{9}$

$\mathrm{He}$ accepts the second premise as obviously true, but recognizes that the first premise is anything but obvious. He notes that the subject of the generation of air from water is not at all apparent to the senses. By contrast, it is quite evident to the senses that the subject stays the same when cold water becomes hot. So, while there is no problem with recognizing one subject underlying any accidental change, he needs to show how we can produce an argument that would also hold for cases of substantial change. This very short argument raises quite a number of issues and we need to proceed cautiously here. He is clearly accepting as a base-line assumption that substantial change exists-e.g., air becomes water-on the basis of sense. Zabarella is not in the business of calling into question such Aristotelian starting points. Thus, he tells us that the minor premise is obvious (manifestum). Yet it must be admitted that calling the premise "obvious" only makes sense within an Aristotelian framework, so we should recognize that "obvious" is ultimately a theory-laden term for him. What proves to be obvious is merely that which Zabarella already knows as a good Aristotelian. The lesson here is that it may be more important to see how Zabarella proves the existence of matter than to worry about whether the proof actually succeeds. Zabarella already knows prime matter exists, but the discovery of prime matter is very much a methodological issue related to explaining what he knows.

Moving on to the major premise, then, how can we know it to be true? Zabarella argues that we need a broader claim that will apply to the more particular claim of the argument's major premise. What we need, in fact, is to show that:

(4) A subject is required in all cases of change.

If that can be shown to be true, then it can be shown that:

(5) There must be a subject for substantial change. 
And (5), of course, is simply (1) slightly restated. Zabarella is thus pinning his hope on the possibility that by starting with the most obvious case of change requiring a subject-that is, easily observable accidental change-we can come to know by a certain proportion (proportione quadam) that a non-observable subject is required for substantial change. ${ }^{10}$

The process by which we can move from accidental change to all change is characterized as "induction." He provides us with a description of the role induction can play in acquiring the knowledge that will justify the major premise: "This is the power [vis] of demonstrative induction: that from the enumeration of some particulars, the essential connection [essentialis connexus] of the predicate with the subject comes to light [in lucem] from which we know it to be so in the remaining particulars." ${ }^{11}$ For this reason, then, Zabarella plans to make use of a demonstrative induction designed to elicit knowledge of a universal proposition. Again, though, this description of induction is theoretically rich, and in order to see the point of his argument for the major premise, we would do better to pay attention to his methodology. That methodology rests on an elaborate foundation of types of knowledge.

Zabarella recognizes four levels of knowledge. The basis for distinguishing such levels is two-fold. On the one hand, the type of knowledge is indexed to the role of the known object within a theory. So, those objects that are effects are known differently than those that are causes. On the other hand, cognition itself can be of two types: confused and distinct. Zabarella summarizes:

We cognize the effect confusedly when, without cognition of its cause, we know the effect. We cognize the effect distinctly when we cognize it through the cognition of the cause. Indeed, the former is called cognition that it is, the latter why it is, and at the same time what it is, since it is the same thing to cognize what it is and why it is. ... Now the cognition of a cause is also sometimes confused and sometimes distinct. Indeed, it is confused when we cognize that it is, but are ignorant about what it is, but it is distinct when we cognize also what it is, and penetrate into its nature. ${ }^{12}$

From this four-fold distinction, it should be clear that there is no such thing as knowledge simply speaking, and when Zabarella states that the minor premise of his syllogism is "obvious," we need to know exactly what the status of our knowledge of that premise is. So too, when he writes of the "power of induction," we need to know just what kind of knowledge is generated by induction.

In addition, Zabarella has given an account of the various ways in which knowledge of causes and effects can be gained. The highest form of knowledge is demonstrative knowledge, which proceeds from distinct 
knowledge of the cause and demonstrates the necessary connection of the effect with the cause, thereby providing distinct knowledge of the effect. The other type of demonstrative knowledge is a demonstration of the cause through the effect. The first tells us what the essence of something is, while the latter merely shows that the relevant thing exists. Hence, the knowledge gained of the cause is confused in relation to its essence-that is, we do not know what it is. Zabarella summarizes:

For all scientific advance [progressus] from the known to the unknown is either from a cause to an effect or from an effect to a cause. The former indeed is the demonstrative method; but the latter is the resolutive method. There is no other process that brings forth certain knowledge of a thing. For if we advance from something to something else, neither of which is the cause of the other, it is not possible for there to be an essential or necessary connection between them. Hence, no certain cognition can follow from the advance. Therefore, it follows that there is no scientific method besides the demonstrative and resolutive ones. ${ }^{13}$

At the same time, though, Zabarella recognizes two types of resolution. One, which is properly called a "demonstration from an effect," is used to make clear that which is exceedingly obscure and hidden. The other type of resolution starts with what we know, but where what we know needs a little additional explanation. This second type of resolution is induction. ${ }^{14}$

The key to understanding the distinction between demonstration from an effect and induction rests on what we know by nature, where "known by nature" means that which is sensible. ${ }^{15}$ Zabarella advances a rather broad notion of what is sensible, though, since the category of sensible things includes not only those things that are singular, but also those universals whose singulars are sensible. So, for example, the universal 'human being' can be considered sensible not because we see the universal but because individual human beings are sensible. In addition to this sortal notion of what is known by nature, Zabarella also holds that certain sorts of propositional claims are known by nature, for example, "human beings are bipedal." We need only observe an individual human being to know that any human being is bipedal. The point here is that such propositional knowledge is immediate (statim) and not inferential. Everything known by nature, whether sortal or propositional, is known by what Zabarella calls a "proper light" (proprius lumen), and such non-inferential knowledge is the result of induction.

By contrast, what is unknown by nature is either unable to be sensed from its singulars or requires some inferential process through 
which it can be known. To illustrate the sortal notions not known by nature, Zabarella points to prime matter and states that matter is not known by a proper light, but is made known by another light. In fact, since it is completely hidden from the senses, it is never known per se, but is made known through another, namely, through the notion of generation. As an example of propositional knowledge that is not known by nature, Zabarella mentions the claim that "a triangle has three angles equal to two right angles." This propositional fact is unknown by nature because the predicate cannot be discerned by the senses, but must be known through another. In other words, no matter how long we look at it, mere inspection of a triangle will never show us that these three angles before us are equal to two right angles. For that knowledge, we need a demonstration.

A natural question to ask next is what underwrites the distinction between what is known per se and what is known through another. The distinction rests on the fact that there are two different sorts of principles, namely, those that can be known directly by the senses (or through induction based on sensory experience) and those that cannot be known through the senses and must be known some other way. Now there is an ambiguity in the term "principle," since, as Zabarella notes, there are principles of a thing, principles of a science, and principles of knowing. Despite this proliferation of different types of principles, Zabarella insists that what they have in common is that they can either be known by the senses or they must be known through a demonstration. It is the former sort of principle that can be known per se, and whether that is a principle of a science or an intrinsic principle of an existing thing, its knowledge is unmediated and induction will play a role when going beyond the knowledge of the singular.

In summary, then, the notion of induction that Zabarella possesses is a method by which we can go immediately from particular instances to the universal, whether the universal be a sortal notion or a propositional one. While it is useless in leading us to what is unobservable, it is useful, thanks to the natural light of the mind, in helping us to know the universal of which the particulars are instances. Hence, induction is merely a process by which we come to "see" the universal in the particular.

Returning now to the argument for the existence of prime matter in the De prima rerum materia, we can fill out the programmatic text from the De regressu with an actual example of Zabarella constructing an induction. The first point to stress is that in Zabarella's description of the induction that warrants the claim that a subject is required in all cases of change, he explicitly flagged that the induction would proceed by a "certain proportion." It turns out that by "proportion" he means 
that the induction is based on the following analogy: Just as bronze is related to a statue, so prime matter is related to a composite substance. In addition, just as the bronze existing prior to the statue is not actually a statue, but is potentially a statue, so too prime matter grasped as prior to being informed is not actually any being (ens), but is potentially any being. ${ }^{16}$ It must be admitted that this quick analogy seems insufficient to warrant acceptance of the universal proposition that a subject is required in all cases of change. Does Zabarella really think that induction is this easy and certain? He provides a bit more clarification by describing the type of analogy he is using:

The analogy is a proportion, which since it is a likeness of ratios [rationum], cannot be between two [terms] (since a ratio is between two), but is between four [terms]. Hence, when we compare two ratios among themselves and say they are similar, we consider four terms (or three if one is assumed twice and takes the place of two terms). For we say that four has a double ratio to two; thus twelve has a double ratio to six. Therefore, since the same ratio exists for each, we say that twelve is related to six in this way-as four is related to two. And this is called analogy. ${ }^{17}$

With this sense of analogy in place, Zabarella continues: "And, so, through this analogy prime matter is known since it corresponds by a proportion to the subject of accidental change." ${ }^{18}$

Through this analogy Zabarella thinks that he can assert that there is a subject matter presupposed in all instances of change, and since that is a universal statement that shows a necessary connection between the subject matter and change, the more particular claim that there is a subject matter underlying substantial change is justified. In this way, he has his demonstration from an effect and has proven to his satisfaction the existence of prime matter. Nonetheless, the reader of Zabarella can be forgiven for thinking that this induction in support of the existence of prime matter underlying substantial change is brief and lacks a certain probative force. Is this merely a case of Zabarella having a "bland confidence"19 in the intellect's ability to apprehend necessary connections? I believe that this claim does not give Zabarella enough credit. Admittedly, he thinks that induction will get us to a universally applicable concept of change, but there is a bit more going on here than appears in the rather perfunctory induction Zabarella provides.

A clue to what is going on is given a bit later in the treatise on prime matter: "For unless we observe water cease to be and changed into air, we could know by no reason that these bodies are composed of matter and form. Instead, we would think them completely simple." ${ }^{20}$ It is only because we observe (inspicere) natural objects changing that we can 
begin to think about the fact that they are composites of matter and form. So, too, then, through induction, Zabarella is making the point that our knowledge of the existence of matter can arise only from a given observational experience of change. By expanding the claim that accidental changes require a subject matter into the universal claim that all change requires a subject matter, Zabarella advances to a universal claim about all change. That premise granted, and the additional observational fact of natural change, he can conclude to the existence of prime matter as underwriting natural change. While Zabarella is a realist and essentialist about natures, it does not follow that he thinks those natures are simply given by the intellect. Instead, he has shown that there is an interplay between observation, experience, and reasoning that stands behind his proof for the existence of matter. It should also be noted that he does not yet claim that the knowledge reached by induction and resolution is revelatory of the nature of matter. All he has done is show that if there is accidental change, there is also substantial change. Items in the world are not eternal, but come into being and perish. The analogy with bronze does no more at this point than explain what it is that all change has in common. After all, it is hardly implausible to call both the heating of water when it is cold and the evaporation of water instances of change.

Since he has been accused of confusion in arguing by induction to the presence of an unobservable cause, it is worth considering one more point raised by the induction Zabarella uses. ${ }^{21}$ As we saw above, he is quite clear that induction cannot be used to argue for something unobservable, but the induction Zabarella gives does not conclude to something unobservable. All it does is suggest that there is an analogy or similarity between our observation of cold water being heated and our observation of water evaporating. Based on the similarity among these two observations, he arrives at a universal judgment about change, based on the observation of accidental change. Once he has an understanding of the similarity among types of change, thanks to analogical reasoning, he can grasp the universal major premise of the resolutive argument from the effect. It is that argument, not the induction, that is used to argue for the unobservable existence of prime matter.

\section{Discovering the Essence of Matter}

So far, we have seen, Zabarella provides a resolutive argument for the existence of matter in natural bodies based on a notion of substantial change arrived at through induction. But the proper goal of scientific methodology is to explain effects in the natural world by their proper causes. Accordingly, he must explain what exactly substantial change 
is through understanding clearly its proper cause. This is the final stage of the regressus, in which the major premise of its first demonstration is converted and used to show that the previously argued-for effect is, once clearly understood, the cause of the observationally known feature of the world essentially connected with the cause. In other words, we must come to an understanding of matter such that we recognize matter to be the cause of substantial change, and not just something that has an essential connection to substantial change. From the mere fact of the existence of matter, though, we are in no position to explain how it is that matter is a cause of substantial change. The next step in the theory of demonstrative regress consists in rendering the confused knowledge of the discovered nature into a distinct knowledge of the nature such that we understand it to be a cause. This task is accomplished by a "mental examination" or "consideration" (mentale examen seu consideratio) of the cause, or, in the traditional language of regressus theorists, a negotiatio intellectus. His schematic account of this mental consideration in the fifth chapter of the $D e$ regressu is justly famous. He continues using prime matter as his example:

In the first place, he [Aristotle] explained how matter differed from privation, for it is the function of matter to stand under contraries, and to receive them, but it is the function of contraries to drive one another mutually out of the same matter. Therefore, matter remains beneath both contraries and is never destroyed. And since the principle of all natural bodies, which must be matter, also must be suited to receive every form and every privation, therefore, according to its proper nature, matter must be committed to no form, no definite nature, and no affection, but free of and immune to all these, since what appears within prevents the attachment of any extraneous thing to it. Matter must, then, according to its own nature, lack every form and possess the capacity to receive all forms. This is, without doubt, the nature of matter, that it be nothing in actuality, but all things potentially, for all things fall under it. $^{22}$

\section{A bit later he continues:}

We easily come to know that such matter is a cause of generation because it has the power of receiving every form, and it prescribes no certain form for itself, but is equally suited to receive a form and its privation. Therefore, it happens that nothing having matter can be perpetual, but is necessarily at some time corrupted, and from it another is generated. ${ }^{23}$

I have quoted these two passages at some length not only because of their importance in determining the shape of Zabarella's regress argument concerning the essence of matter, but also because it has been 
claimed that the second passage follows from the first, only because of a "startling illogicality" on Zabarella's part. ${ }^{24}$ I am not so sure. One reason why I worry about too quickly accusing Zabarella of illogicality is that the discussion of the distinct knowledge of matter as a cause is given in much greater depth in the treatise on prime matter than in the brief discussion of the De regressu. Putting that consideration aside for the moment, though, I am not certain that there is even an illogicality present in the De regressu since there is another crucial claim that connects these two passages:

\begin{abstract}
Now, what led us to this knowledge is first that confused knowledge of matter that was previously given, and then that comparison with generation by which it was discovered. Thus we learn little by little what place matter has in generation and what its function is so that we may distinguish it from the functions of other principles. Once the function is known, the individual conditions come into the light that are necessary for it to be able to serve a given function. ${ }^{25}$
\end{abstract}

Zabarella does not try to argue from the fact that matter is pure potentiality to the claim that matter is the cause of generation - that is, substantial change-without any intermediate step. It is only if the intermediate step does no useful work for the argument that we could claim an illogicality. But the intermediate step is precisely the famous mental consideration of the regressus theory, and Zabarella makes it quite clear in the passage quoted immediately above that the mental consideration involves learning "little by little" the nature of matter and that learning can only be done by discovering matter's function. Subsequently, from a discovery of its function, the conditions of matter become clear through an extended investigation. It is only after this lengthy consideration that we can say that we know distinctly the nature of matter as it is the cause of substantial change. This lengthy consideration is not given in the De regressu, though, and the reader of Zabarella must turn to the treatment of the nature of matter in the De prima rerum materia for a full example of a mental consideration. Hence, I will defer a decision about Zabarella's illogicality for now, instead turning to his attempt to take the confused cognition of matter previously discovered through the demonstration from an effect and clarify it in such a way as to render his knowledge of matter distinct.

\title{
4. The Mental Consideration of the De prima rerum materia
}

The purpose of the mental consideration is to provide us with the nature and conditions (conditiones) of the cause. Arriving at a distinct knowledge of this cause, we can then demonstrate why an effect follows from its cause. This is an important consideration, since it shapes the 
entire focus of Zabarella's investigation. The effect that he is trying to understand is substantial change. And what he wants to prove is that prime matter explains substantial change. He can do so only if he can show, by mental consideration, that we can assert that where matter exists, there is substantial change. That is, he must show that the major premise of the demonstration from the effect is convertible. At the same time, he can take for granted the conclusion of his proof for the existence of matter, so that he knows that there is a connection between matter and natural bodies. Thus, we have the following argument:

(1) Where there is matter, there is substantial change.

(2) In natural bodies there is matter.

Therefore,

(3) In natural bodies there is substantial change.

The mental consideration that Zabarella elaborates on in the De prima rerum materia is lengthy and rather technical. In what follows, I will do no more than highlight the most important points he makes in light of what he needs for the regress argument: a clear knowledge of the nature of matter that makes it convertible with substantial change.

As we saw, though, Zabarella makes a distinction between two notions of matter: matter considered as it is in itself, and matter considered as it is a principle of things. It is the latter notion that he uses for his mental consideration. Now, in considering matter as it relates to other principles of things, Zabarella tells us that there are two primary attributes of matter: privation and potency. These are, recall, the two terms he contrasts to matter in the De regressu. Thus, the extended discussion of privation and potency in relation to matter considered as a principle of things is just what one would expect in light of that programmatic text.

Privation is not to be confused with negation. Negation is the universal absence of all forms, while privation is a principle of natural things insofar as it is the terminus a quo of generation and the terminus ad quem of destruction. Accordingly, privation is always conjoined with some prior form generating that form to which the privation is opposed, and constituting in matter the potency for receiving some subsequent form. The idea here is simple enough. Privation, as opposed to simple absence or negation, occurs only when there is a transition from one form to another and the privation attached to the first form is such that the second form can actually arise from it. So, for example, it is wrong to say that a stone possesses the privation of human nature. The stone simply lacks human nature because a stone can never become human. By contrast, the privation of human nature does exist along 
with human seed, since that seed is precisely something out of which human nature arises. Privation, then, serves two functions in an account of any change, whether substantial or accidental. ${ }^{26}$

Given this general understanding of privation, what is the precise way in which it can be an attribute of matter? The key point for our purpose is that privation must accompany matter insofar as privation is necessary for generation. This necessity means that while matter absolutely considered can exist without privation, just as it can exist without form, nonetheless generation cannot be explained without both matter and privation. As Zabarella puts it: "It is necessary that whatever is generated is generated from matter having been deprived [privata]."27 His point is simple enough. Any change requires matter, privation, and form. Take away any one of these principles and no change is possible. But that just means that if we consider matter as a principle, not as it is in itself, we never find it existing without privation. In fact, Zabarella states this conclusion even more strongly: Taking matter as a principle of things, matter is always formed (formatam) and qualified (qualem) since privation and potency exist in it. ${ }^{28}$

As this last assertion makes clear, it is not only privation that exists as a necessary attribute of matter when it is considered as a principle of things; potency is also an attribute of matter so considered. There is an immediate complication, though, in Zabarella's discussion, since he goes on to make a distinction between universal and particular potency. Matter is said to have universal potency insofar as it is indifferent to any form or privation, while it has particular potency insofar as it is determined and restricted to receive one form and not another. This latter feature of matter is not due to the nature of matter itself, but rather to an agent preparing the matter for receiving one form and not some other form. Particular potency also includes the status of matter as it is already informed, that is, as it possesses certain qualities that predispose it to develop in one way and not another. So, for example, an acorn has a particular potency to become an oak tree given its form and qualities, and, for that reason, it cannot become a cat. This distinction between universal and particular potency requires Zabarella to take into account both sorts of potency in his discussion of matter considered as a principle of things. ${ }^{29}$

Unlike the particular potency of matter, its universal potency is merely its ability to receive all forms. This potency is the very essence of matter in its role as a principle of things. For this reason, we can say that it is because matter has the potentiality to receive all forms that it is a material principle. This universal potency, then, is as it were the nature (ratio) and form of matter, and Zabarella concludes: "When we consider matter as a principle, the essence of matter is directed to 
receiving a form." ${ }^{30}$ By contrast, the particular potency of matter is not essential to it. This fact should not surprise us, since that which is accidental to something is what it does not need in order to be in potency or to exist actually. But matter does not need to be the matter of a human being to exist; it need only be the principle of something else. Since no one particular potency can prevent matter from being able to be a principle of something, particular potency is not essential. So too, matter must be able to exist without a particular potency. After all, how could it receive a particular potency if it did not already exist? ${ }^{31}$ At the same time, though, Zabarella does not want us to forget that even in the case of particular potency, we need to distinguish between the potency it has to a form and that which makes it to be the form of one kind of thing and not another. In the case of the acorn, we need to recognize that the matter of the acorn has a potency to receive the acorn's form, and as potency to receiving form, it is essential to the nature of matter, not merely accidental; it is part of the very nature of the acorn's matter considered as a principle. The accidental feature of matter's particular potency is found only in its having been prepared by some prior privation for taking on a particular form. Therefore, Zabarella thinks that even the particular potency of matter is essential to matter insofar as it is a potency to receive a form. It is only its potency to receive some particular form that is accidental to the nature of matter. ${ }^{32}$

\section{Conclusion: The Essence of Matter and the Completion of the Regressus}

From this brief account of Zabarella's view concerning matter as a principle of things, we can return to the question of the strength of his claim that matter is the cause of substantial change. Recall that the worry involved seeing how, from the mere assertion that matter is not a privation and does not possess any form intrinsically, Zabarella could derive a distinct knowledge of matter as the cause of natural change. By bringing in a consideration of the essence of matter from the $D e$ prima rerum materia, however, I hope to have shown that there is not a "startling illogicality" involved. In his ex professo methodological, albeit schematic, treatment of the mental consideration required for regressus, he explicitly called for an investigation of the function and conditions of the effect demonstrated through the first stage of the regressus. In his discussion of privation and potency, he has provided that investigation. That he fails to do so in the De regressu may be unfortunate, but it is an oversight amply compensated for in the De prima rerum materia. 
The account that emerges through the extended mental consideration is one in which we are led to acknowledge that matter as a principle of things has a nature such that it can explain substantial change. By virtue of its association with privation and its universal and particular potency to receive any form, it is clear that any change is dependent on matter. Thus, we can happily explain substantial change by reference to the nature of matter without the threat of startling illogicality. Indeed, we are led to see that matter must have a connection with substantial change, and that the connection must be a causal one.

Nonetheless, it is worth reflecting on why it is that Zabarella views matter in this way. And here he is quite explicit and frank. He tells us that the analogy with the statue is at the root of his choice of attributes:

For after we discover that matter exists through substantial change, we consider that it thus relates to things that arise from it, as bronze relates to the statue whose matter it is. And since the relation [ratio] of bronze to the statue is known, hence we conclude to what the relation of prime matter is to things that arise from it. For, before bronze receives the form of the statue, it is not actually, but only potentially, the statue. Therefore, since the relation of prime matter to all things is the same as the relation of bronze to the statue, matter also will not be anything actual from things, but will be all things potentially. ${ }^{33}$

This admission on Zabarella's part is striking confirmation of his thorough Aristotelian commitments. It turns out that the entire account of matter spins out of his meditation on a basic example provided by Aristotle and his use of the elaborate regressus method ultimately leads to a systematic appreciation of, and justification for, this example.

While one might wonder about the wisdom of subscribing to this account of matter in the first place, and thereby accuse Zabarella of only explaining Aristotle and not discovering for himself the truth about matter, such an accusation would not worry him. After all, explaining Aristotle's text and arguing in an Aristotelian manner are his stated purposes in the treatise on prime matter. ${ }^{34}$ Yet Zabarella is no mere servile expositor of Aristotle's texts despite his intentions. His account of Aristotle is deeply systematic, indeed, systematic in ways that Aristotle is not. For this reason, trying to understand one thread of Zabarella's thought requires familiarity with his entire corpus. Logical problems quickly become methodological ones, but the methodological ones presuppose accounts of knowledge and its acquisition. The ingenuity, power, and consistency of his defense of Aristotle are quite powerful rethinkings of the Aristotelian tradition. Indeed, this strikingly thorough defense of Aristotle is not one found in Aristotle's text, and 
Zabarella's philosophical creativity is better viewed in this light than in any purported imperfect foreshadowing of subsequent thinkers. Moreover, I have tried to show that he succeeded-on his terms-in providing both a systematic method that would justify his defense of Aristotle and that his extended application of that method is not obviously flawed in its logic. We might have wanted Zabarella to do something different, but he can hardly be faulted for carrying out his stated intention in an ingenious and powerful way.

\section{NOTES}

1. For Zabarella's life and writings, see the helpful account in William F. Edwards, "The Logic of Jacopo Zabarella (1533-1589)" (PhD diss., Columbia University, 1960), pp. 1-82. Also useful is Charles Lohr, Renaissance Authors, vol. 2 of Latin Aristotle Commentaries (Firenze: L.S. Olschki, 1988), pp. 497-503. The fundamental study of Zabarella's influence in Germany is Peter Petersen, Geschichte der aristotelischen Philosophie im protestantischen Deutschland (Leipzig: F. Meiner, 1921). For more information on the place of Zabarella's logical writings in later history, see Neal W. Gilbert, Renaissance Concepts of Method (New York: Columbia University Press, 1963), pp. 211-8; William F. Edwards, "Paduan Aristotelianism and the Origins of Modern Theories of Method," in vol. 1 of Aristotelismo Veneto e scienza moderna. Atti del 25. Anno Accademico del Centro per la Storia della Tradizione Aristotelica nel Veneto, ed. Luigi Olivieri (Padua: Antenore, 1983), pp. 206-20. In his Hegel and Aristotle (Cambridge: Cambridge University Press, 2001), Alfredo Ferrarin extends the story of Zabarella's influence into the nineteenth century.

2. Jacopo Zabarella, De prima rerum materia, bk. I, chap. 6, col. 142C-D: "Quemadmodum igitur homini alia attribuuntur, quatenus homo, alia, quatenus est pater; sic etiam materiae alia sunt attributa secundum primam eius notionem, et prout ens, alia vero iuxta secundam notionem quatenus est principium, et refertur ad alia." This treatise appears in Zabarella's De rebus naturalibus libri $X X X$, first published in Venice in 1590. In what follows, I use the reprint (Frankfurt: Minerva, 1966) of the 1607 edition of the work published in Frankfurt. The De prima rerum materia is divided into two books. In subsequent notes, I will refer to this work as DPRM, followed by book, chapter, and column numbers. This and subsequent translations are mine.

3. DPRM II.2, 183D: "Sed hac de re Theologicam disputationem dimittamus. ... Consilium meum est non Theologice, sed Aristotelice disputare."

4. DPRM I.1, 133E: "Nisus fuero veritatem, et Aristotelis de prima materia sententiam (si possim) reddere clariorem." 
5. DPRM I.2, 135D-E: "Generari autem et interire dicimus proprie quidem et absolute substantias, accidentia vero minu proprie, et (ut vocant) secundum quid: nam si ex aere aqua generetur, aquam fieri simpliciter dicimus; si vero aqua ex frigida fiat calida, non simpliciter dicimus aquam fieri, sed aquam fieri calidam; unde colligimus, eandem mutationem in accidentibus vocari posse et generationem et motum quo variis considerationibus: illam enim aquae calefactionem generationem appelare possumus, quatenus sit calidum ex non calido, formatum ex privato; quatenus autem est transitus a frigido in calidum, a forma ad formam, et (ut vocant) a positivo ad positivum, eatenus vocatur motus."

6. The literature on the regressus theory is vast. A very helpful discussion of the treatise and its background can be found in Antonino Poppi, La dottrina della scienza in Giacomo Zabarella (Padua: Antenore, 1972), pp. 27794. Extended treatments of issues surrounding regressus can be found in Charles B. Schmitt, "Experience and Experiment: A Comparison of Zabarella's View with Galileo's in De motu," in Studies in Renaissance Philosophy and Science (London: Varorium Reprints, 1981), pp. 80-138; and "Aristotelianism in the Veneto and the Origins of Modern Science: Some Considerations on the Problem of Continuity," in vol. 1 of Aristotelismo Veneto e scienza moderna, pp. 104-24; Giovanni Papuli, "La teoria del regressus come metodo scientifico negli autori della Scuola di Padova," ibid., pp. 221-78; Wilhelm Risse, "Zabarellas Methodenlehre," ibid., pp. 155-72. Particularly significant is the essay by Nicholas Jardine, "Galileo's Road to Truth and the Demonstrative Regress," Studies in the History and Philosophy of Science 7 (1976), pp. 277-318. All of these works build on and react to the pioneering work of John H. Randall's The School of Padua and the Emergence of Modern Science (Padua: Antenore, 1961). Randall argues that Zabarella's view is a logic of investigation and discovery. Note that this book was based on a paper published in 1940 titled "The Development of Scientific Method in the School of Padua," Journal of the History of Ideas I (1940), pp. 177-206. For a later restatement of his view, see "Paduan Aristotelianism Reconsidered," in Philosophy and Humanism: Renaissance Essays in Honor of Paul Oskar Kristeller, ed. Edward P. Mahoney (New York: Columbia University Press, 1976), pp. 275-82. See also the defense of Randall by William F. Edwards, "Randall on the Development of Scientific Method in the School of Padua," in Naturalism and Historical Understanding, ed. John P. Anton (Albany: SUNY Press, 1967), pp. 53-68. A modified version of the thesis that Aristotelianism played a key role in the development of modern scientific method can be found in a series of articles and books by William A. Wallace. See, as examples, "Reinterpreting Galileo on the Basis of his Latin Manuscripts," in Reinterpreting Galileo, Studies in Philosophy and the History of Philosophy, vol. 15, ed. William A. Wallace (Washington D.C.: Catholic University of America Press, 1986), pp. 3-28; and "Randall Redivivus: Galileo and the Paduan Aristotelians," Journal of the History of Ideas 49 (1988), pp. 133-49.

7. Zabarella, De regressu, 1, 481C-D, in his Opera logica (Cologne, 1597): "Est enim reciprocata quaedam demonstratio, qua postquam causam ignotam ex effectu noto demonstravimus, maiorem propositionem convertimus, et eundem effectum per eandem causam demonstramus, ut scia- 
mus propter quid sit." I have used the 1966 reprint of the 1597 edition of the Opera logica (Hildesheim: Ohms, 1966). I cite this work by chapter and column numbers. The translation is mine. Zabarella first published the De regressu as well as the other logical treatises I use in this essay at Venice in 1578. I would like to thank John Longeway for many helpful conversations about Zabarella's logical writings.

8. See Schmitt's "Experience and Experiment" for an extended discussion of Zabarella's notion of discovery. I hope to treat this issue in more detail on a later occasion.

9. DPRM I.3, 136D.

10. DPRM I.3, 136E.

11. DPRM I.3, 136F: "Haec enim est vis inductionis demonstrativae, ut ex aliquorum particularium enumeratione in lucem prodeat praedicati cum subjecto essentialis connexus, unde cognoscamus ita esse in reliquis."

12. Zabarella, De regressu 4, 484E-F: "Effectum confusem cognoscimus, quando absque causae cognitione novimus ipsum esse: distincte vero, quando per cognitionem causae: illa quidem dicitur cognitio quod est, haec vero propter quid est et simul etiam quid est: quoniam idem est cognoscere propter quid est. . . . Datur tamen causae quoque cognitio tum confusa, tum distincta: confusa quidem, quando ipsam esse cognoscimus, sed quidnam sit ignoramus: distincta vero, quando cognoscimus etiam quid sit, et ipsius naturam penetramus."

13. Zabarella, De methodis, III.17, 265F-266A, in his Opera Logica: "Omnis enim a noto ad ignotum scientificus progressus vel a causa est ad effectum, vel ab effectu ad causam; illa quidem est methodus demonstrativa, haec autem resolutiva; alius processus, qui certam rei notitiam pariat, non datur: nam si ab aliquo ad aliquod progrediamur, quorum neutrum alterius causa sit, non potest inter illa esse connexus essentialis, ac necessarius. Quare nulla certa cognitio illum progressum consequi potest; patet igitur, nullam dari scientifica methodum praeter demonstrativam, et resolutivam." I cite this work by book, chapter, and column number. The translation is mine.

14. Zabarella also makes a distinction between two types of induction, dialectical and demonstrative. Dialectical induction requires us to know every particular that falls under the induction. It is only demonstrative induction that helps us to know the causes of things since it alone can go from some observable cases to an inference about all cases. For the distinction between the two kinds of induction, see De regressu, 4, 485C-D.

15. This paragraph and the next summarize the De methodis, III.19.

16. DPRM I.4, 137D-E. Aristotle famously uses the example of bronze and the statue in relation to change and matter at Physics I.7, 191a9-12.

17. DPRM I.4, 137E-F: "Analogia enim est proportio, quae quum fit similitudo rationum, non potest esse inter duo, sed est inter quatuor, quia ratio est inter duo, quare dum duas rationes inter se comparamus, et similes esse dicimus, quatuor terminos consideramus, vel tres, si unus bis 
sumatur, et teneat locum duorum; dicimus enim, quaternarium ad binarium habere rationem duplam, sic duodenarium ad senarium habere rationem duplam; quum ergo eadem utrobique sit ratio, dicimus ita se habere duodenarium ad senarium, ut se habet quaternarius ad binarium, eaque vocatur analogia."

18. DPRM I.4, 138A: "Et ita per hanc analogiam cognoscitur prima materia, quia proportione respondet subiecto mutationis accidentalis."

19. Jardine, "Galileo's Road to Truth and the Demonstrative Regress," p. 301. It is unfortunate that in Jardine's very useful essay, he supplies Zabarella with an account of cognition which Zabarella does not hold. Jardine believes that Zabarella's identification of the Agent Intellect with God means that God reveals the essential natures of things. To the contrary, Zabarella's identification of the Agent Intellect with God has little bearing on his account of intellectual cognition, which is instead based on a rejection of standard medieval abstractionist accounts of knowledge. It is that mistake that underwrites Jardine's assertion of bland confidence. For an overview of Zabarella's account of human cognition, see Poppi, La Dottrina della Scienza in Giacomo Zabarella, pp. 65-130. I have made an initial attempt to show the orientation of Zabarella's account of human knowledge in my essay "Zabarella and the Intentionality of Sensation," Rivista di storia della filosofia 57 (2002), pp. 5-25.

20. DPRM I.5, 139F: "Nisi enim interire aquam, et in aerem mutari videremus, nulla ratione cognoscere posseramus corpora haec ex materia et forma constare, sed simplicia penitus esse putaremus."

21. In "Galileo's Road to Truth and the Demonstrative Regress," p. 300, Jardine claims that Zabarella is guilty of contradiction in holding that (a) induction does not reach beyond what is observable and that (b) the demonstration from an effect that he uses to prove the existence of prime matter goes beyond what is observable and yet relies on induction.

22. Zabarella, De regressu, 5, 488C-E: "Docuit in primis quomodo a privatione differat: materiae namque officium est substare contrariis, et ea recipere: contrariorum vero officium est se ab eadem materia mutuo pellere: ideo materia manet sub utroque contrario, et nunquam interit: et, quum omnium naturalium corporum principium, et materia esse debeat, debet etiam esse talis, quae omnes formas, et omnes privationes recipere apta sit: itaque nulli formae, nulli certae naturae, nulli affectioni addicta esse debet secundum propriam eius naturam, sed ab omnibus libera, et immunis: quia intus apparens prohibet extraneum: debet igitur materia secundum suam naturam carere omnibus formis, et omnium recipiendarum potestatem habere: haec absque dubio est natura materiae ut nihil sit actu, sed potestate omnia, in hunc enim sensum cadunt omnia."

23. Zabarella, De regressu, 5, 488F: "Facile nobis innotescit, talem materiam generationis causam esse: quoniam enim potestatem habet recipiendi omnes formas, et nullam certam formam sibi praescribit, sed aeque apta est recipere formam, et eius privationem: ideo facit ut nullum materiam habens possit esse perpetuum, sed ex necessitate aliquando intereat, et ex eo aliud generetur." 
24. Jardine, "Galileo's Road to Truth and the Demonstrative Regress," p. 302.

25. Zabarella, De regressu, 5, 488E: “Ad eam autem cognitionem nos duxit tum cognitio illa praecedens confusa quod materia detur, tum eius comparatio cum generatione , ex qua fuit inventa: sic enim paulatim discimus, quem locum in generatione habeat ipsa materia, et quod nam eius officium sit, idque ab aliorum principiorum muneribus distinguimus: officio cognito conditiones singulae in lucem prodeunt, quae ut fungi tali officio possit, necessariae sunt."

26. See DPRM I.7, 145-51 for an extended discussion of privation, absence, and negation.

27. DPRM I.8, 152C: "Necessarium enim est ut quidquid generatur, generetur ex materia privata."

28. DPRM I.8, 153A.

29. DPRM I.10, 159-60.

30. DPRM I.13, 169-70. The quotation appears at 170C: "Nam essentia materiae ad formam recipiendam dirigitur, dum materiam at principium consideramus."

31. DPRM I.14, 171A.

32. DPRM I.14, 171E-F.

33. DPRM I.5, 138F-139A: "Postquam enim materiam dari per substantiae mutationem invenimus, consideramus eam ita se habere ad res, quae ex ipsa fiunt, ut se habet aes ad statuam cuius est materia, et quum ratio aeris ad statuam nota sit, inde colligimus, quae sit ratio primae materiae ad res quae ex ea fiunt; aes enim antequam formam statuae accipiat, non est actu statua, sed potestate: quoniam igitur eadem est primae materiae ratio ad res omnes, quae aeris ad statuam, materia quoque non erit ulla ex rebus actu, sed omnes potestate."

34. For a helpful discussion of Zabarella's explicit defense of his practice, see Antonino Poppi, "Zabarella, or Aristotelianism as a Rigorous Science," in The Impact of Aristotelianism on Modern Philosophy, ed. Riccardo Pozzo (Washington, D.C.: The Catholic University of America Press, 2004), pp. 35-63. Poppi summarizes Zabarella's position: "One should not see, however, anything humiliating in this spiritual activity [of interpreting Aristotle], because if one sets oneself to the school of such famous masters, one acquires knowledge's maximum bonum, its highest good, something by means of which we approach divine life" (38). 